\title{
Protein Signatures of Remodeled Airways in Transplanted Lungs with Bronchiolitis Obliterans Syndrome Obtained Using Laser-Capture Microdissection

Catharina Müller, * Oskar Rosmark, ${ }^{*}$ Emma Åhrman, ${ }^{* \dagger}$ Hans Brunnström, ${ }^{\ddagger \S}$ Katharina Wassilew, ${ }^{\llbracket}$ Annika Nybom, * Barbora Michaliková, ${ }^{*}$ Hillevi Larsson, Leif T. Eriksson, ${ }^{* \|}$ Hans H. Schultz, ${ }^{* *}$ Michael Perch, ${ }^{* *}+\dagger$ Johan Malmström, Jenny Wigén, ${ }^{*}$ Martin Iversen, ${ }^{* *}$ and Gunilla Westergren-Thorsson*

From the Lung Biology Unit,* Department of Experimental Medical Science, the Divisions of Infection Medicine ${ }^{\dagger}$ and Pathology, ${ }^{\ddagger}$ Department of Clinical Sciences Lund, and the Department of Respiratory Medicine and Allergology," Skåne University Hospital, Lund University, Lund, Sweden; the Division of Laboratory Medicine, ${ }^{\S}$ Department of Genetics and Pathology, Region Skåne, Lund, Sweden; the Department of Pathology and the Department of Cardiology, ** Section for Lung Transplantation, Copenhagen University Hospital, Rigshospitalet, Copenhagen, Denmark; and the Department of Clinical Medicine ${ }^{\dagger \dagger}$ University of Copenhagen, Copenhagen, Denmark

\author{
Accepted for publication \\ May 12, 2021. \\ Address correspondence to \\ Gunilla Westergren-Thorsson, \\ Ph.D., Department of Experi- \\ mental Medical Science, Lund \\ University, Sölvegatan 19, BMC \\ C12, 22184 Lund, Sweden. E- \\ mail: gunilla.westergren- \\ thorsson@med.lu.se.
}

\begin{abstract}
Bronchiolitis obliterans syndrome, a common form of chronic lung allograft dysfunction, is the major limitation to long-term survival after lung transplantation. The histologic correlate is progressive, fibrotic occlusion of small airways, obliterative bronchiolitis lesions, which ultimately lead to organ failure. The molecular composition of these lesions is unknown. In this sutdy, the protein composition of the lesions in explanted lungs from four end-stage bronchiolitis obliterans syndrome patients was analyzed using laser-capture microdissection and optimized sample preparation protocols for mass spectrometry. Immunohistochemistry and immunofluorescence were used to determine the spatial distribution of commonly identified proteins on the tissue level, and protein signatures for 14 obliterative bronchiolitis lesions were established. A set of 39 proteins, identified in $>75 \%$ of lesions, included distinct structural proteins (collagen types IV and VI) and cellular components (actins, vimentin, and tryptase). Each respective lesion exhibited a unique composition of proteins (on average, $n=66$ proteins), thereby mirroring the morphologic variation of the lesions. Antibody-based staining confirmed these mass spectrometry-based findings. The 14 analyzed obliterative bronchiolitis lesions showed variations in their protein content, but also common features. This study provides molecular and morphologic insights into the development of chronic rejection after lung transplantation. The protein patterns in the lesions were correlated to pathways of extracellular matrix organization, tissue development, and wound healing processes. (Am J Pathol 2021, 191: 1398-1411; https://doi.org/ 10.1016/j.ajpath.2021.05.014)
\end{abstract}

Since the first lung transplantations in the late 1980s, bronchiolitis obliterans syndrome (BOS) in the form of progressive airway obstruction has been recognized as the most important pathology associated with adverse outcome. The first definition and guideline for BOS was issued in $1993,{ }^{1}$ with revisions in $2002,{ }^{2} 2014,{ }^{3}$ and $2019 .^{4}$ The term BOS was defined as progressive airway obstruction causing $>20 \%$ decline in forced expiratory volume in 1 second with no obvious reason, like infection or other macroscopic lesions. The pathologic correlate to BOS was identified as
Supported by the Swedish Medical Research Council 2016-01190 (G.W.-T.), the Evy and Gunnar Sandberg Foundation 2015 (G.W.-T.), the Swedish Heart-Lung Foundation 20190297 (G.W.-T.), the Alfred Österlund Foundation 20191209 (G.W.-T.), the Royal Physiographic Society in Lund 20191114 (G.W.-T.), the Swedish Foundation for Strategic Research SBE13-0130 (G.W.-T.), ALF 2018 Project0097 Government Public Health grant (G.W.-T.), and the Inga and John Hains Foundation 20170906 (C.M.).

Disclosures: M.P. reports grants from Roche, nonfinancial support from Boeringer-Ingelheim, and personal fees from Novartis, Astra-Zeneca, and Mallinckrodt, outside the submitted work. 
obliterative bronchiolitis (OB) lesions. These lesions were, however, small and patchy and could not be diagnosed reliably with radiology or transbronchial biopsies. ${ }^{3}$ BOS has been demonstrated in both single-center studies ${ }^{5}$ and the International Society for Heart and Lung Transplantation registry studies ${ }^{6}$ to afflict nearly all lung transplant patients. The median BOS-free survival is 3 to 4 years, and 10 years after transplantation, BOS, in some degree, is present in $90 \%$ of patients.

BOS was initially used synonymously to chronic lung allograft dysfunction, as the most common type of chronic lung allograft dysfunction. However, other subtypes are now recognized by distinct clinical parameters and histopathologic features, most prominently restrictive chronic lung allograft dysfunction/restrictive allograft syndrome. $^{7-10}$ The present study focused on BOS lesions. Studies have suggested that immunologic processes in non-BOS lesions are different from BOS. ${ }^{11,12}$ The histopathologic correlates of BOS, the OB lesions, develop on remodeling of the small airways, although the events leading to the occlusions are not completely understood. ${ }^{13}$ Epithelial cell death has been suggested as a key event in the development of $\mathrm{BOS}^{14}$ and may trigger exaggerated wound healing, where mesenchymal cell activities, including buildup and turnover of extracellular matrix, subsequently obliterate the airway. ${ }^{15}$ In an innovative study, micro-computed tomography was used to demonstrate the patchy nature of OB lesions. ${ }^{16}$ The lesions were minute, affecting mainly small peripheral airways with a diameter of $<2 \mathrm{~mm}$. Furthermore, the lesions appeared to be heterogeneous, probably due to different developmental stages.

This study seeks to characterize these $\mathrm{OB}$ lesions in BOS exhibiting fibrotic occlusion of the small airways, by using a unique combination of laser-capture microscopy (LCM), mass spectrometry (MS), and antibody-based staining to combine state-of-the art protein identification and spatial information on the tissue level. Thereby, it provides a snapshot view of ongoing events in OB lesions. Molecular profiling of the pathologic lesions in BOS is desirable to elucidate the cellular components and events initiating and driving the disease, with the aim to find new molecular tools to intervene. ${ }^{17}$ Thorough histopathologic studies have advanced the knowledge in this field by using complex imaging methods, protein analysis, and gene analysis. ${ }^{16,18-21}$ Characterization of these lesions is challenging because of their focal nature, scarcity in the lung, and the small amount of material available for analysis. Herein, we use a novel approach to increase the depth of MS protein identification and to describe the protein signatures of 14 pathologically remodeled airways in four end-stage BOS patients. This exploratory study, by exquisitely dissecting out the lesions and carefully excluding confounding tissue surrounding the OB lesion, identified cellular pathways involving extracellular matrix organization, tissue development, and wound healing processes that warrant further investigation, with the aim of finding therapeutic targets.

\section{Materials and Methods}

\section{Clinical Data}

Lung tissue was obtained from four patients in two centers (Skåne University Hospital, Lund, Sweden; and Copenhagen University Hospital, Rigshospitalet, Copenhagen, Denmark). The patients had end-stage BOS as a complication of lung transplantation. Lung tissue material was obtained from the explanted lungs after retransplantation.

Patient characteristics are shown in Supplemental Table S1. Informed consent and ethical permit were obtained at the respective center (Lund dnr 2015-89), and data were obtained from Scandiatransplant (dnr 2007-58-0008). Every patient consented to the explanted lung to be used for research. Healthy lung tissue was obtained from Sahlgrenska Hospital, Gothenburg, Sweden (ethical permit, Gothenburg, dnr 2008/413), and informed consent was obtained.

\section{Sample Preparation}

The study is based on OB lesions identified in lung explant tissue. The formalin-fixed explanted lungs underwent thorough macroscopic examination, and the tissue was extensively sampled, typically with at least one central (containing bronchus) and two peripheral tissue blocks per lobe. Tissue samples were dehydrated and paraffin embedded according to routine pathology procedures. Using a microtome, tissue sections ( $4 \mu \mathrm{m}$ thick) were produced and placed on routine glass slides (Menzel Superfrost Plus; VWR, Stockholm, Sweden) for hematoxylin/eosin (HE) staining, immunohistochemistry (IHC), immunofluorescence (IF), and LCM [in Auto-laser pressure catapulting (LPC) mode]; or polyethylene (PEN)-membrane slide (Zeiss, Stockholm, Sweden; Membrane Slide 1.0 PEN, 415101-4401-000) for LCM (in Robo-LPC mode). Before usage, PEN slides were activated by 30 minutes of UV irradiation $(254 \mathrm{~nm})$ using a Spectrolinker/Crosslinker XL1000 UV (DOT Scientific Inc., Burton, MI).

Tissue blocks from the four patients were available for the research study. A large amount of tissue was processed, and submitted according to the protocol for macroscopic examination of explanted lungs. During the processing, tissue sections were placed alternating on routine glass slides or PEN-membrane slides (Supplemental Figure S1). Because of their high cost, it was not feasible to use PEN-membrane slides for all of the material. Depending on where OB lesions were identified in consecutive, HE- and elastica van Gieson-stained sections, OB lesion material was lifted during LCM from routine or PEN-membrane slides. According to our data and the instrument manufacturer's data (Zeiss), this does not affect the quality of the protein retrieval after LCM. 


\section{Identification of $\mathrm{OB}$ Lesions}

OB lesions containing tissue blocks were identified by a pathologist at the respective center (H.B. in Lund and K.W. in Copenhagen). A total of 50 to 100 sections were produced from each tissue block, and a systematic screening for OB lesions was performed using HE-stained tissue sections in regular intervals at different depths of the specimen (Histolab, Askim, Sweden; Mayer's hematoxylin/eosin, according to manufacturer's instructions). Once identified, consecutive tissue sections were used for LCM, IF, and IHC (Figure 1). Identification of OB lesions during the screening procedure was done at the Lung Biology Group, Lund, and lesions were then reviewed independently by the two pathologists at the respective center (H.B. in Lund and K.W. in Copenhagen). Only lesions for which the pathologists' assessments were in concordance were included in the study. Lesions where precise delineation could not be performed by LCM because of technical difficulties were excluded. No further material was considered when a satisfactory number of lesions was established. A satisfactory number was not reached for patient 4 (only one lesion included in the study) because of lack of well-delineated and suitable OB lesions.

\section{Immunohistochemistry and Immunofluorescence}

Consecutive sections to the ones used for HE and LCM were used for antibody-based staining of selected proteins of interest, as previously published. ${ }^{22}$ After deparaffinization, heat-induced epitope retrieval was performed on a PT Tissue Link system (Histolab) using citrate buffer. IHC for collagen $\alpha 1$ and 2 (IV) chains and tryptase was performed using the EnVision Dual Link System (K4065; Dako, Glostrup, Denmark), according to manufacturer's instructions, including horseradish peroxidase-coupled secondary antibodies and counterstaining with Mayer's hematoxylin to visualize nuclei. IF for periostin, collagen $\alpha-1$ (VI) chain, $\mathrm{Ki}-67$, and $\alpha$-smooth muscle actin ( $\alpha$-SMA; aortic smooth muscle actin) was performed by incubation with primary antibodies for 1 hour and with fluorochrome-coupled

\section{End-stage \\ BOS explants \\ Dissection of tissue samples}

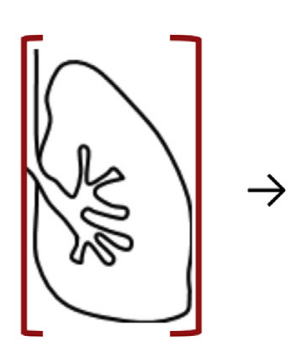

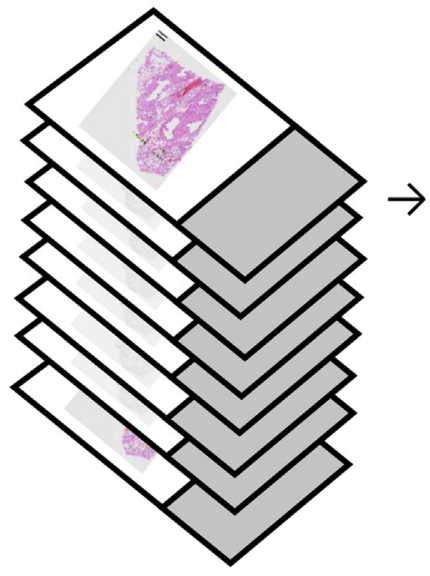

Identification of

OB lesions

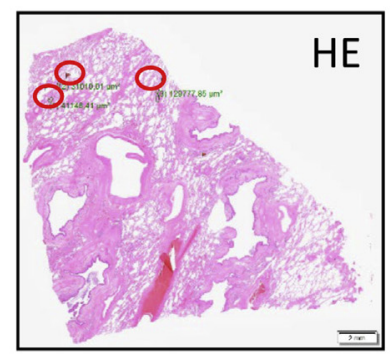

Laser-capture microdissection

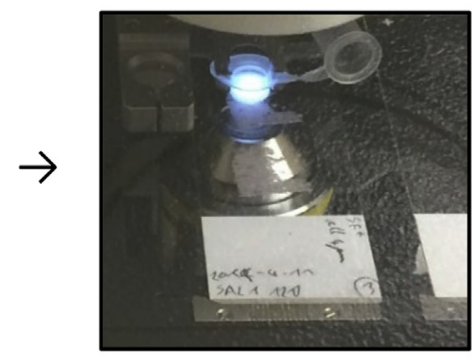

\section{Mass spectrometry sample preparation}

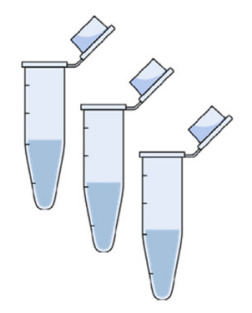

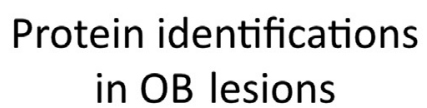

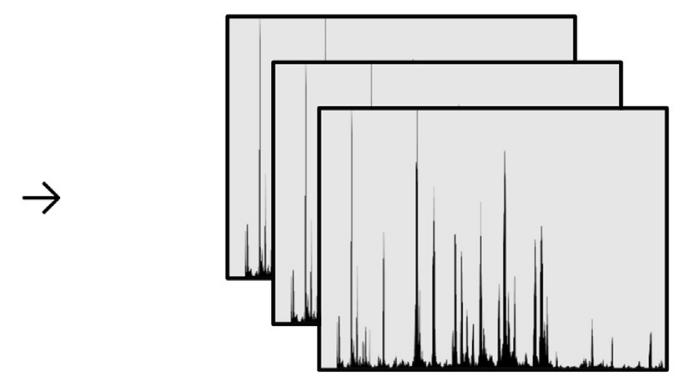

\section{IF/IHC for \\ proteins of interest}

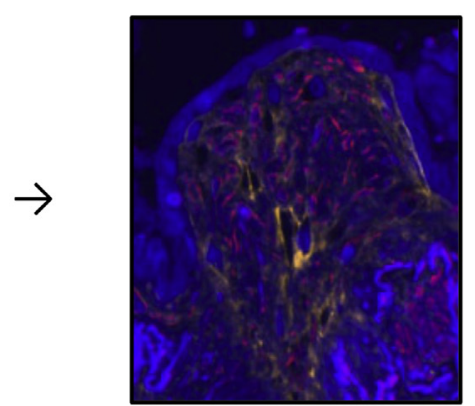

Figure 1 Schematic overview of the experimental workflow. Selection and assessment of consecutive tissue sections for histologic identification of obliterative bronchiolitis (OB) lesions used for of laser-capture microscopy (LCM) tissue extraction. Sample preparation and use of LCM/mass spectrometry for identification of protein targets and immunofluorescence (IF)/immunohistochemistry (IHC) for spatial tissue distribution of proteins of interest. BOS, bronchiolitis obliterans syndrome; HE, hematoxylin/eosin. 
Table 1 Antibody Specifications for the Proteins Detected in Histology

\begin{tabular}{|c|c|c|c|c|c|}
\hline Antibody & Description & Manufacturer, catalog no. & Dilution & Method & Secondary antibody \\
\hline Collagen $\alpha-1$ and $\alpha-2$ (IV) chains & Basement membrane & Abcam (Cambridge, UK), ab6586 & $1: 4000$ & $\mathrm{IHC}$ & $\mathrm{DAB}^{+}$ \\
\hline Collagen $\alpha-1$ (VI) chain & Structural protein & Abcam, ab6588 & $1: 1000$ & IF & A-21246 \\
\hline Periostin & Glycoprotein & Abcam, ab79946 & $1: 100$ & IF & $A-21246$ \\
\hline$\alpha-S M A$ & Cytoskeleton & Sigma (St. Louis, M0), C6198 & $1: 2500$ & IF & Directly conjugated \\
\hline $\mathrm{Ki}-67$ & Proliferation marker & Abcam, ab15580 & 1:1000 & IF & $A-21246$ \\
\hline Tryptase & Mast cell & Dako, Kod M7052 & $1: 100$ & $\mathrm{IHC}$ & $\mathrm{DAB}^{+}$ \\
\hline
\end{tabular}

A, Alexa Fluor (Thermo Fisher Scientific, Waltham, MA), at 1:200; $\mathrm{DAB}^{+}$, diaminobenzidine positive [Dako EnVision + Dual Link System-HRP (K4065)]; IF, immunofluorescence; IHC, immunohistochemistry; $\alpha$-SMA, $\alpha$-smooth muscle actin.

secondary antibodies for 45 minutes. Sections were mounted with ProLong Gold Antifade Mountant with DAPI (Invitrogen, Carlsbad, CA) to visualize nuclei. Nonspecific staining of the secondary antibodies was assessed by omitting the primary antibodies (Table 1).

\section{Image Acquisition}

Images were obtained with a Zeiss fluorescence microscope or with a VS120 virtual microscopy slide scanning system (Olympus, Tokyo, Japan), in either bright-field mode (hematoxylin/eosin and IHC) or fluorescent mode (IF). From the scanned slides, representative images were acquired using the OlyVIA soltware 2.8 (Olympus). Exposure times, acquisition settings, and image brightness adjustments were used consistently for each respective staining, including negative controls, apart from the collagen VI and periostin stainings in healthy control subjects that were performed at a later time point.

\section{Laser-Capture Microdissection}

Tissue sections intended for LCM were deparaffinized $(2 \times$ xylene for 5 minutes, $2 \times$ absolute ethanol for 2 minutes, $95 \%$ ethanol for 1 minute, $70 \%$ ethanol for 1 minute, and two changes of distilled water). OB lesions were previously reported to contain an abundance of hyaluronan; thus, hyaluronidase digest $(0.2 \%$ bovine testicular hyaluronidase; Sigma, St. Louis, MO; type I-S) in acetate buffer (20 mmol/ $\mathrm{L}$ sodium acetate and $150 \mathrm{mmol} / \mathrm{L}$ sodium chloride, $\mathrm{pH}$ 5.2) was performed for 1 hour at $37^{\circ} \mathrm{C}$, to enable effective protein extraction from the microdissected material. ${ }^{23}$ Predigested tissue sections were stained with Mayer's hematoxylin (Histolab) for 30 seconds to visualize nuclei. After three changes of water, sections were dehydrated $(2 \times 95 \%$ ethanol for 1 minute, and absolute ethanol for 2 minutes), air dried, and stored at $-20^{\circ} \mathrm{C}$ in sealed containers. Before LCM, sections were allowed to equilibrate to room temperature, avoiding condensation. LCM was performed on a PALM MicroBeam system (Carl Zeiss MicroImaging, Jena, Germany) using the PALM Robo 4.6 Pro Software (Carl Zeiss MicroImaging), with a $10 \times$ objective. Depending on whether a suitable OB lesion was available on a PEN-membrane glass, Robo-LPC mode (defined larger structures were cut out and lifted in one piece by the laser) was used (Supplemental Figure S1). For OB lesions on regular object glasses, Auto-LPC mode (small tissue fragments were lifted directly off the glass by discrete laser pulses) was used (Supplemental Figure S1). OB lesions were defined by submucosal fibrosis narrowing the bronchiolar lumen, and material within the smooth muscle ring was collected. Dissected material was catapulted into the lids of adhesive cap tubes (Zeiss Adhesive Cap tubes opaque 415190-9201-000; $500 \mu \mathrm{L})$. Images of the slides were acquired using an AxioCamICc1 (Zeiss), and the CapCheck function was used to control successful collection of dissected tissue into the lid.

\section{Mass Spectrometry Sample Preparation}

Samples were prepared according to Braakman et al, ${ }^{24}$ with the modifications of including $8 \mathrm{~mol} / \mathrm{L}$ urea in the extraction buffer and using SP3 beads for peptide desalting. LCM material in the lids of the tubes was dissolved in $20 \mu \mathrm{L} / \mathrm{lid}$ $0.1 \%$ RapiGest w/v (Waters, Milford, MA; 186001861) in $50 \mathrm{mmol} / \mathrm{L}$ ammonium bicarbonate with $8 \mathrm{~mol} / \mathrm{L}$ urea and incubated at room temperature for 30 minutes. Subsequently, the lysate was centrifuged to the bottom of the tube (30 seconds/6082 $\times g$; Biofuge pico, Heraeus; DJB, Buckinghamshire, UK). Tissue slices were sonicated in Bioruptor Plus (Diagenode SA, Seraing, Belgium) at $4^{\circ} \mathrm{C}$ for 20 cycles, 15 seconds on/off. Proteins were denatured at $99^{\circ} \mathrm{C}, 300 \mathrm{rpm}$, for 5 minutes, reduced by incubation with 5 $\mathrm{mmol} / \mathrm{L}$ dithiothreitol at $60^{\circ} \mathrm{C}$ for 30 minutes, and alkylated with $15 \mathrm{mmol} / \mathrm{L}$ iodoacetamide for 30 minutes. Samples were diluted with $50 \mathrm{mmol} / \mathrm{L}$ ammonium bicarbonate to 1.6 $\mathrm{mol} / \mathrm{L}$ urea concentration and digested with $1 \mu \mathrm{g} \mathrm{Lys}-\mathrm{C} /$ Trypsin mix (Promega, Madison, WI) overnight at $37^{\circ} \mathrm{C}$, on an orbital shaker with a $3 \mathrm{~mm}$ orbit, $300 \mathrm{rpm}$. The digestion was stopped by addition of $10 \%$ trifluoroacetic acid to a final concentration of $0.5 \%(\mathrm{v} / \mathrm{v})$, and RapiGest was degraded by incubation at $37^{\circ} \mathrm{C}$ for 60 minutes. The peptide samples were desalted using SP3 beads, as described by Hughes et al. ${ }^{25}$ As the starting material was peptides, the peptide SP3 cleanup procedure was followed. Briefly, acidified peptide samples were supplemented with 4 $\mu \mathrm{L}$ SP3 beads, and acetonitrile was added to a final concentration of $>95 \%$. After incubation for 8 minutes, samples were washed with $100 \%$ acetonitrile. Peptides were 
eluted by incubation for 5 minutes in aqueous buffer with $2 \%$ dimethyl sulfoxide, followed by sonication. Peptide samples were mixed $1: 1(\mathrm{v} / \mathrm{v})$ with $2 \times$ buffer A (4\% acetonitrile and $0.4 \%$ formic acid), giving a final concentration of $2 \%$ acetonitrile, $0.2 \%$ formic acid, and $1 \%$ dimethyl sulfoxide.

\section{Liquid Chromatography-MS/MS Analysis}

The mass spectrometry proteomics data have been deposited to the ProteomeXchange Consortium via the Proteomics Identification Database partner repository (PRIDE, https:// www.ebi.ac.uk/pride/archive/projects/PXD014171, publication date, May 19, 2021). Peptides were separated on an EASY-nLC 1200 high-performance liquid chromatography system (Thermo Fisher Scientific, Waltham MA) using a 50-cm EASY-spray PepMap RSLC C18 column (Thermo Fisher Scientific). For peptide separation, the following segmented gradient of solvent B $(0.1 \%$ formic acid in $80 \%$ acetonitrile) over solvent $\mathrm{A}(0.1 \%$ formic acid) was used: $3 \%$ to $10 \%$ solvent B for 11 minutes, $10 \%$ to $30 \%$ solvent B for 87 minutes, $30 \%$ to $45 \%$ solvent B for 22 minutes, $45 \%$ to $80 \%$ solvent B for 4 minutes, followed by $100 \%$ solvent $\mathrm{B}$ for 10 minutes, using a flow of $350 \mathrm{~nL} /$ minute. Data acquisitions were performed on a Q-Exactive HF-X mass spectrometer (Thermo Fisher Scientific). For data-dependent acquisition, full MS scans were acquired at resolution of 120,000 at $200 \mathrm{~m} / \mathrm{z}$, automatic gain control target 3 million, with maximum injection time of 100 milliseconds at mass range 350 to $1650 \mathrm{~m} / \mathrm{z}$. Each full scan was followed by MS/ MS fragmentation of the top 15 most abundant ions with 30,000 resolution at $200 \mathrm{~m} / \mathrm{z}$, automatic gain control target $3 \mathrm{e} 6$, and maximum injection time of 50 milliseconds.

\section{Data Analysis}

Analysis and searches of raw files were performed in MaxQuant version 1.6.3.3 (https://www.maxquant.org, last accessed May 1, 2019) and Andromeda toward a reviewed UniProt human database with standard contaminants (downloaded November 17, 2015). Default settings were used in MaxQuant and the summed protein intensities were reported for all peptides identified for the respective protein group. Search parameters included trypsin with maximum two missed cleavages at 4.5 parts per million for precursors and 20 parts per million for fragment ions. Carbamidomethylation was set as fixed modification, and methionine oxidation was set as variable. A false discovery rate of $1 \%$ was used for both proteins and peptides. The proteomics data have been deposited to the ProteomeXchange Consortium via the PRIDE partner repository (https://www.ebi.ac.uk/pride/archive, last accessed June 7, 2019) with the data set identifier (PXD014171). ${ }^{26}$ For classification of extracellular matrix proteins, we used the matrisome assignments described by Naba et al. ${ }^{27,28}$ All MS data are summarized in
Supplemental Table S2, presenting information of the number of proteins in each protein group; the number of peptides for each protein group; the summed intensity of the protein group for respective sample; and information regarding how many of the patient samples the protein group was identified in. If not otherwise indicated, data are shown for proteins, which were identified in more than one sample. A minimum CI score of 0.4 was used for the protein network illustration because of low numbers of proteins for these types of statistics. For classification of identified proteins into functional groups, this type of tool can describe potential cellular pathways involved in the pathology of OB lesions. Data were visualized using RStudio version 1.1.442 (RStudio, Boston, MA).

\section{Results}

\section{Histologic Identification of OB Lesions}

Fourteen OB lesions were identified in the pulmonectomy specimens by examination of HE-stained sections from tissue blocks. Seven different lesions were analyzed (OBag) from Patient 1 (P1; P1 OBa-g); 3 from Patient 2 (Patient $2 \mathrm{OBa}-\mathrm{c}$ ); 3 from Patient 3 (Patient $3 \mathrm{OBa}-\mathrm{c}$ ); and 1 from Patient 4 (Patient $4 \mathrm{OBa}$ ). Because of a clear delineation of the lesions and preferably cross-sectioned airways, these lesions were particularly suitable for LCM. Material was collected from each lesion during laser-capture microdissection from several tissue sections (4 $\mu \mathrm{m}$ thick). Consecutive sections of each OB lesion were used for LCM/MS and IHC/IF to characterize their protein content (Figure 1). The lesions exhibited substantial morphologic heterogeneity (Figure 2 and Supplemental Figure S2). No patient-specific histologic pattern was observed. Characteristics of previous studies were confirmed in the submucosal fibrosis with narrowing of the airway lumen, with complete obliteration in Patient $3 \mathrm{OBb}$. This study included three histologic subgroups: i) terminal bronchioles with OB-like features, ii) bronchioles with classic OB, and iii) bronchioles with suspected $\mathrm{OB}$ and muscular hypertrophy.

\section{Proteome Description of the 14 OB Lesions}

LCM was used to select the specific OB lesion regions and data-dependent acquisition MS, followed by data analysis in MaxQuant, to identify and describe the proteome composition of the 14 OB lesions. Proteome analyses were performed on minute amounts of sample, and mean LCMcollected area was $499,131 \mu \mathrm{m}^{2}$ from sections (4 $\mu \mathrm{m}$ thick) (Figure 3A). Variations in number of identified proteins (Figure 3B) did not depend on differences in LCM-collected amount of material (Figure 3A) or LCM type (Figure 3B). Spearman correlation plots were used to visualize correlations between identified proteins within the lesions (Figure 3C). No group cluster associations were found 

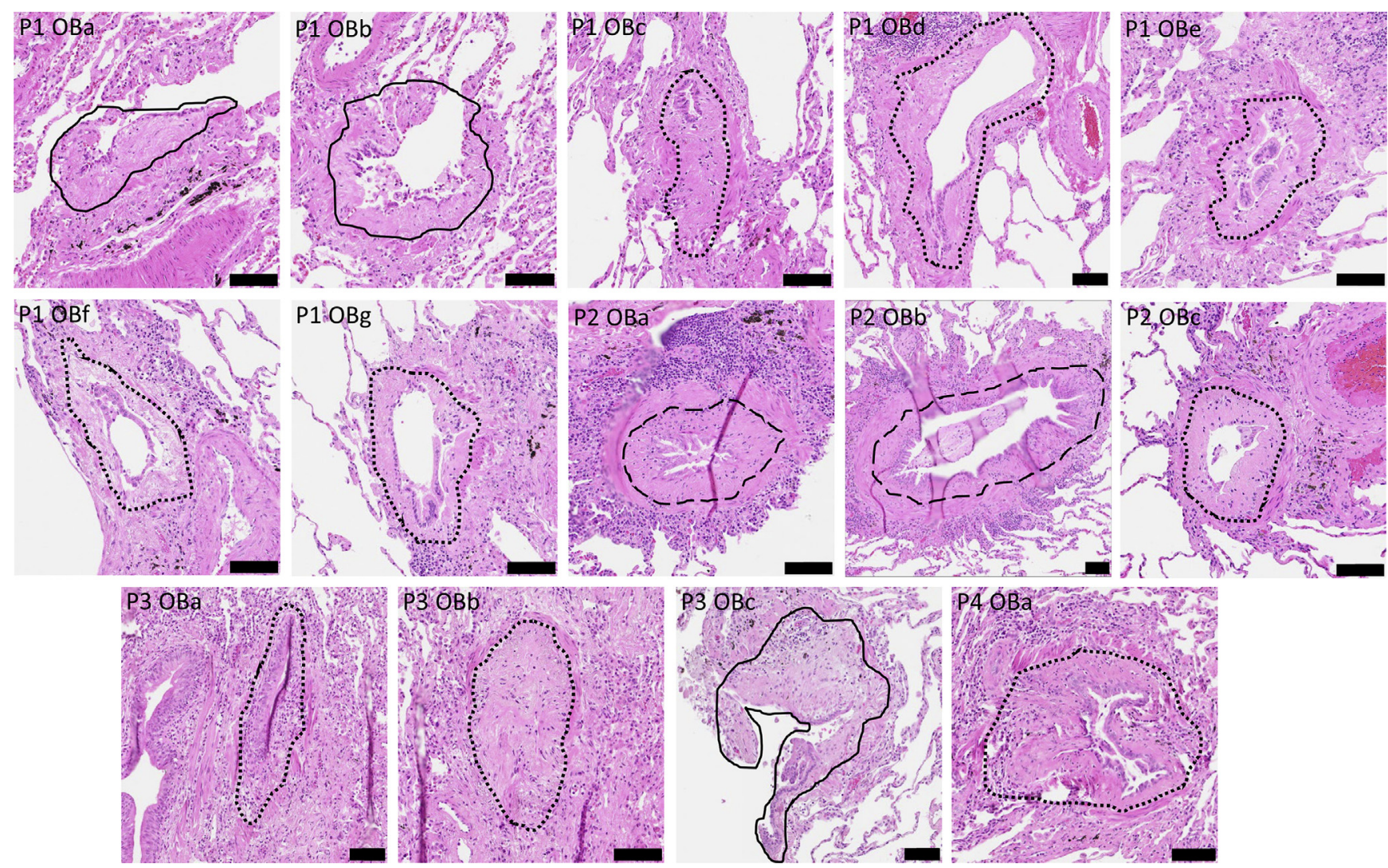

Figure 2 Obliterative bronchiolitis (OB) lesion morphology. Histologic classification of OB lesions (hematoxylin/eosin) exhibiting different morphologic features. Patient samples were grouped into the following three subgroups: i) terminal bronchiole with OB-like features (solid lines), ii) bronchiole with OB (dotted lines), and iii) bronchiole with suspected $\mathrm{OB}$, with smooth muscle hypertrophy (dashed lines), based on histologic classification. Scale bars $=100$ $\mu \mathrm{m}$. P1 to P4, Patients 1 to 4 .

within the analyses when evaluating LCM type used during microdissection, histologic subgroup of the OB lesions, or patient belonging. This suggests that these parameters do not drive the resulting proteome correlations within the $\mathrm{OB}$ lesions. The proteome correlations varied from 0.16 to 0.84 between the samples. A separate correlation matrix was constructed, excluding the single lesion analyzed from $\mathrm{Pa}-$ tient 4 (Supplemental Figure S3A), finding a similar result.

For functional annotation of the identified proteins within the OB lesions, the protein network obtained with STRING database (Figure 4) was used to show the suggested proteinprotein interactions. The biological process with the gene ontology term extracellular structure organization showed the highest representation, and proteins within this node are visualized in red. The nodes with gene ontology terms tissue development (green) and response to wounding (blue) were selected for visualization. The enrichment of proteins associated with extracellular structure organization in the OB lesions suggests this pathway to be of high importance. Excluding the single lesion from Patient 4 did not alter the protein network as none of the proteins was unique for this lesion. Validation and spatial distribution of proteins within this node are further evaluated in representative OB lesions with MS and histology staining.

\section{Representative Proteins in OB Lesions}

To further capture proteomic similarities within the OB lesions, sample presence was visualized by showing how often the same proteins were identified in each OB lesion and the proteins' $\log 10$ abundance distribution (Figure 5A). From these analyses, the protein candidates identified in $>75 \%$ of samples were selected and visualized in a heat map (Figure 5B). This cutoff was accepted as a threshold because this represented, after careful analysis of other cutoffs (such as present in more than one sample or present in $50 \%$ or $100 \%$ of the samples), the best-balanced representation of the data. These 39 proteins represent the selection of protein candidates descriptive for OB lesions. Analyzing the data by excluding the single sample obtained from Patient 4 showed similar results (Supplemental Figure S3B). A complete list with identified proteins in each OB lesion is presented in Supplemental Table S2 (MS data).

Next, six structural extracellular matrix proteins were selected [collagen $\alpha-3$ (VI) chain, collagen $\alpha-1$ (VI) chain, collagen $\alpha-2$ (VI) chain, collagen $\alpha-2$ (IV) chain, collagen $\alpha-1$ (IV) chain, and periostin (Figure 5B)], and their spatial distribution was analyzed within the $\mathrm{OB}$ lesions using 


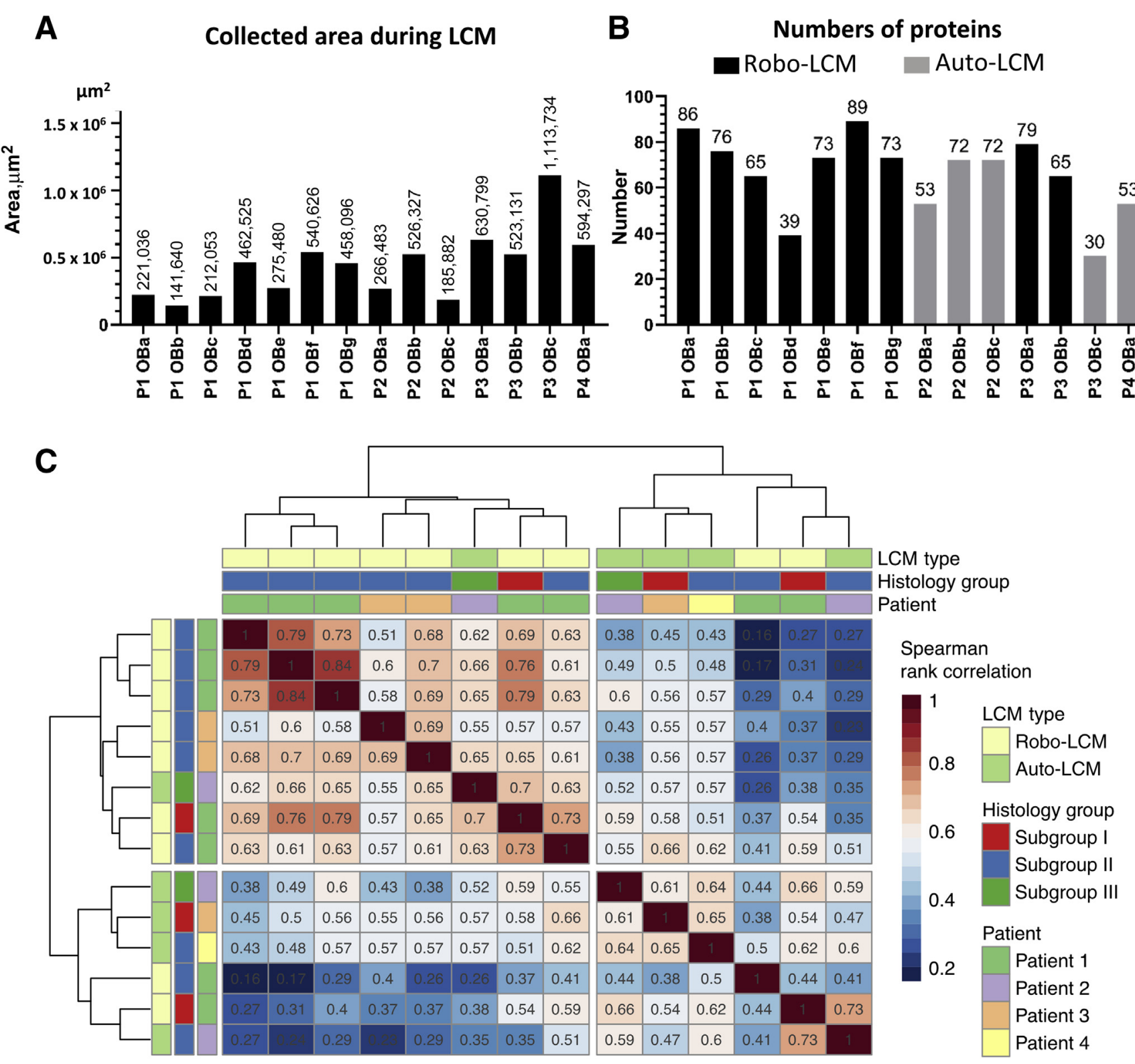

Figure 3 Laser-capture microscopy (LCM)-mass spectrometry description of obliterative bronchiolitis (OB) lesions. A and B: For each OB lesion, the collected total area (A) and the number of identified proteins and LCM mode (B) were estimated. C: The Spearman rank correlations between samples take proteins into account that were identified in more than one lesion. LCM type used during collection of samples, histologic subgroup, and patient belonging are included in the legend. Spearman rank correlation is colored from red (high correlation) to blue (low correlation). P1 to P4, Patients 1 to 4.

immunohistochemical stainings. These proteins were chosen because of their importance in the basement membrane (BM) structure and how they are affected during pathologic tissue remodeling of airways, which in BOS may result in disruption of the epithelial barrier, thereby leading to disease progression.

Accumulation of Collagen Type IV, Collagen Type VI, and Periostin in $\mathrm{OB}$ Lesions

To characterize the fibrotic compartment of the $\mathrm{OB}$ lesions, collagen type IV, as identified by MS, was selected and its histopathologic distribution was characterized by IHC/IF.

Collagen type IV, an exclusive BM component, was identified by both its $\alpha-1$ and $\alpha-2$ chains by MS (Figure 6 , A and $\mathrm{B}$ ) in 11 of the 14 lesions. Figure $6 \mathrm{C}$ shows smooth muscle and bronchiolar BM staining as expected (normal). Distinct variations in collagen type IV deposition, well mirroring the MS results, were seen in different lesions. P1 OBa showed extensive deposition of collagen type IV in the fibrotic protrusion, whereas Patient 2 OBa showed a thickened, positive bronchiolar BM. Patient $3 \mathrm{OBc}$ had a relatively low deposition of collagen type IV (Supplemental Figure S4). Similarly, collagen type VI was detected by 


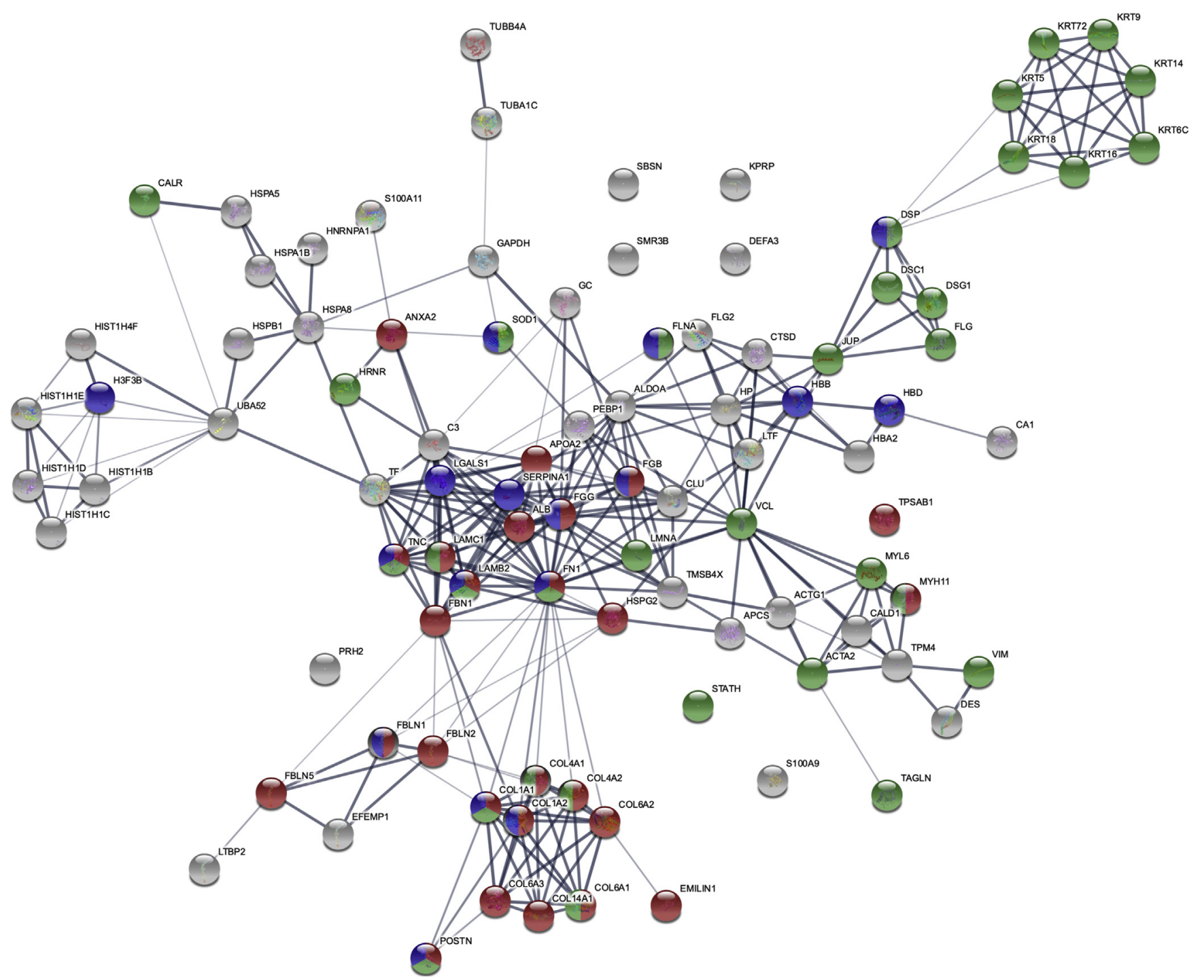

Figure 4 Search Tool for the Retrieval of Interacting Genes/Proteins (STRING) database analysis of all proteins identified within the obliterative bronchiolitis lesions. Gene ontology group annotations are colored: red, extracellular structure organization; green, tissue development; and blue, response to wounding. The line thickness indicates the strength of confidence of data support, where the minimum required interaction score was set to 0.4 (medium confidence). GAPDH, glyceraldehyde-3-phosphate dehydrogenase.

MS in all lesions (Figure 7A). Strong deposition of collagen type VI in the fibrotic protrusions within the OB lesions was seen by IF in most lesions; however, this was not seen in the ones classified as suspected $\mathrm{OB} / \mathrm{smooth}$ muscle hypertrophy (Figure 7C and Supplemental Figure S5). Similarly, periostin was identified by both MS (Figure 7B) and IF (Figure 7D) in selected lesions. Distinct periostin accumulation was found in the fibrotic areas protruding into the airway lumen, most prominently in sample P1 OBa and P1 $\mathrm{OBb}$, as well as in generalized submucosal fibrosis in P1 OBc. IF staining of collagen type VI in healthy control bronchiolar tissue typically resided in basal membrane and is present throughout the subepithelial space inside the smooth muscle ring, whereas periostin staining was mainly visible outside the smooth muscle ring (Supplemental Figure S6).
Accumulation of $\alpha$-SMA- and Tryptase-Positive Cells in $\mathrm{OB}$ Lesions

IF staining for $\alpha$-SMA was used to detect the smooth muscle wall of the pulmonary airways surrounding OB lesions, but also identified an accumulation of positive cells with an elongated cell shape in the fibrotic protrusions (Figure 7, C and D). These likely represent myofibroblasts, according to morphologic features. Cells in the OB lesions were negative for the proliferation marker Ki-67 (Supplemental Figure S7), but some were positive for tryptase (Supplemental Figure S8A), indicating presence of mast cells. OB lesions with low levels of tryptase (Supplemental Figure S8B) looked similar to the healthy control (Supplemental Figure S8D), whereas high tryptase levels in the MS analysis, Patient 3 (Supplemental 
A Sample

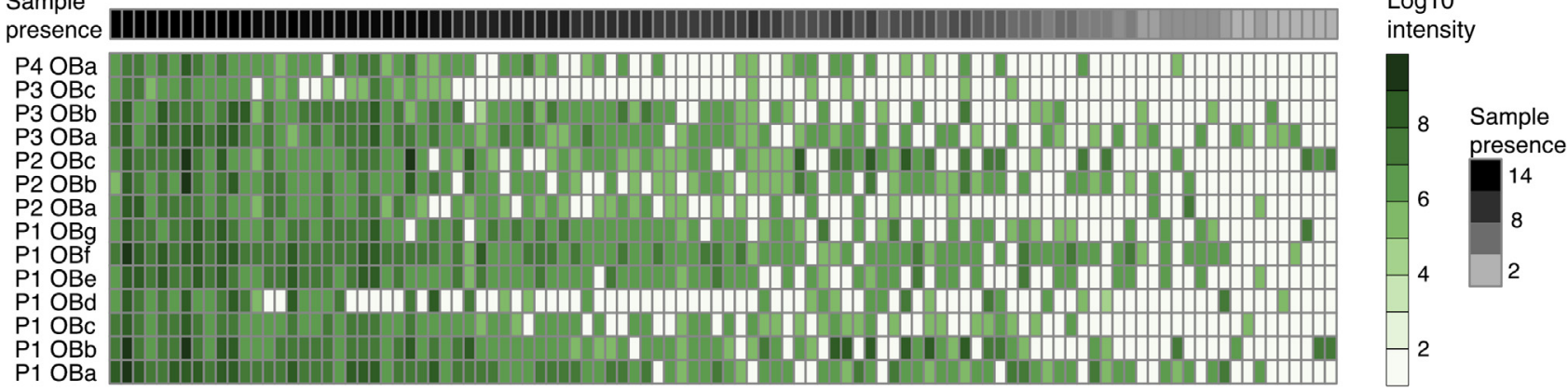

B

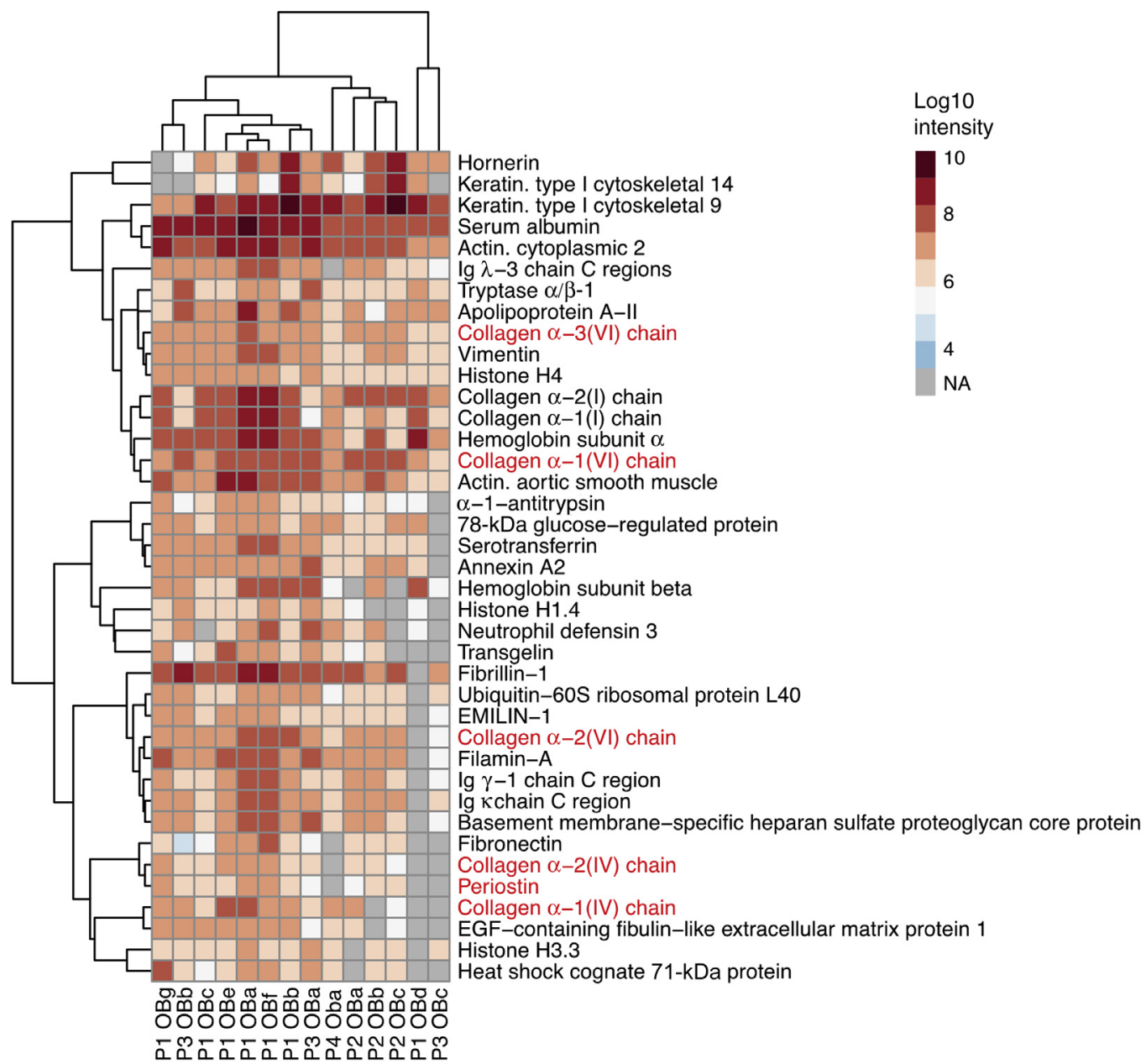

Figure 5 Proteomic characterization of obliterative bronchiolitis (OB) lesions. A: Sample presence and log10 intensity distribution of identified proteins within $\mathrm{OB}$ lesions. B: Heat map with unsupervised hierarchical clustering of proteins representatively present in $>75 \%$ of the characterized $0 \mathrm{~B}$ lesions. Terms marked in red show the structural extracellular matrix proteins used for further spatial tissue distribution. EGF, epidermal growth factor; EMILIN, elastin microfibril interfacer; NA, not applicable; P1 to P4, Patients 1 to 4.

Figure S8A), showed more prominent tryptase staining (Supplemental Figure S8C) compared with healthy control airways (Supplemental Figure S8D).

\section{Discussion}

This study shows a link between the morphologic appearance of OB lesions in remodeled airways in lungs from patients experiencing end-stage BOS and their respective protein content. Protein signatures of the OB lesions correlate to extracellular matrix organization, tissue development and wound healing processes, and aberrant BM composition. Interestingly, these findings corroborate results from earlier studies from our group obtained in a larger patient cohort, where early extracellular matrix changes were shown to be associated with later development of BOS. ${ }^{29}$ In line with this, previous findings demonstrate that the vascular endothelial growth factor/vascular endothelial 
A

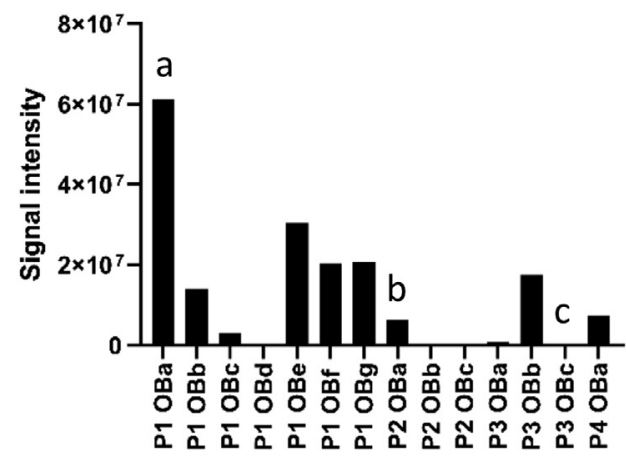

B

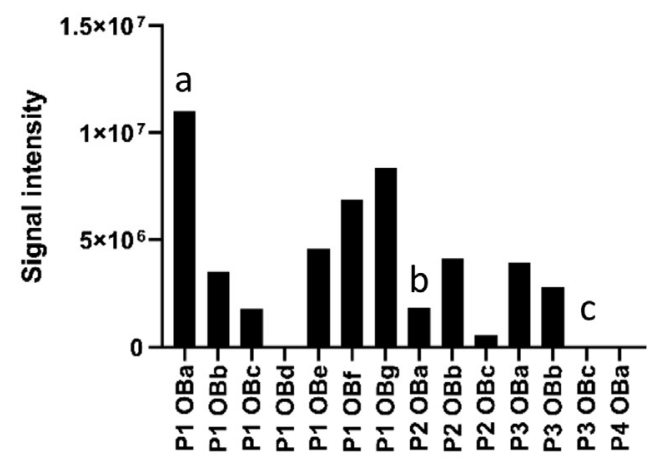

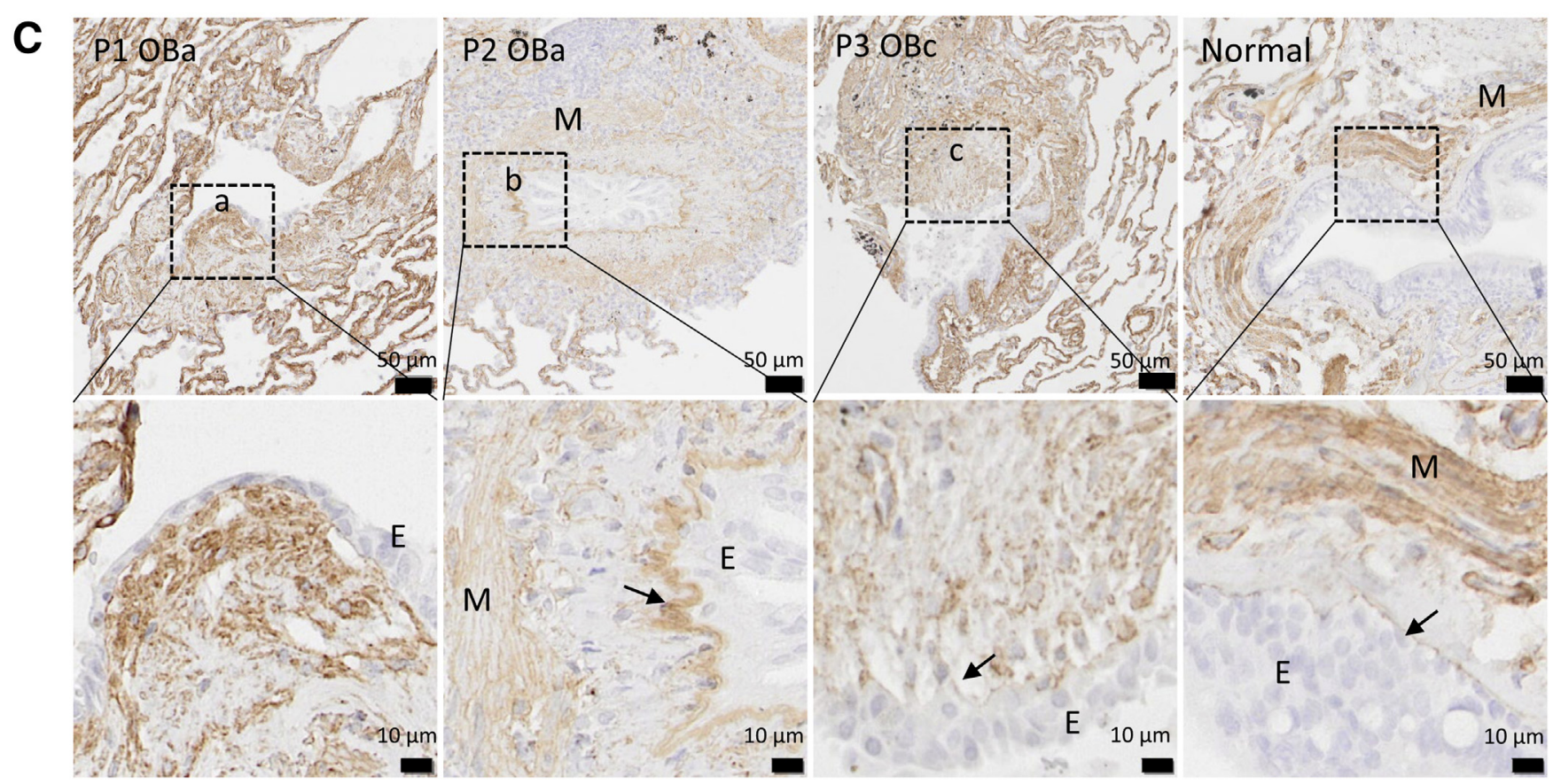

Figure 6 Collagen type IV immunohistochemistry (IHC). A and B: Corresponding signal intensities from laser-dissected regions analyzed by mass spectrometry for the collagen type IV $\alpha 1$ (A) and $\alpha 2$ (B) chain. C: IHC for collagen type IV, depicting areas of high intensity (a), low intensity (b and c), and bronchiolar basement membrane ( $b$ and arrows) staining of collagen type IV in selected obliterative bronchiolitis (OB) lesions as well as in an airway unaffected by fibrosis (normal). Positive collagen type IV staining, brown. Scale bars: $50 \mu \mathrm{m}$ (C, top row); $10 \mu \mathrm{m}$ (C, bottom row). E, epithelium; M, airway smooth muscle; P1 to P4, Patients 1 to 4.

growth factor receptor 2 axis is involved in early signs of OB lesions and may serve as a marker for bad prognosis. ${ }^{30}$ Moreover, total collagen, collagen type IV, and biglycan were found at an early stage, 3 months after transplantation, and were predictive of later development of OB lesions, which was also confirmed in this study. ${ }^{29}$ A possible mechanism may include the release of biglycan from the extracellular matrix on tissue stress, which contributes to increased fibroblast migration and release of transforming growth factor (TGF)- $\beta$, a prominent actor in fibrosis. ${ }^{31,32}$ Keratins 5, 9, and 14 are detected in the OB lesions (Figure 4). Keratin 5 is a marker for basal cells, and keratin 14 is expressed by basal cells during lung inflammation and is, as keratin 9, involved in intracellular intermediate filaments, which have an impact on cell migration during lung tissue repair. ${ }^{33-35}$ Keratin $6 \mathrm{c}$, also found in the OB lesions (Figure 4), is important for epithelial-mesenchymal transition and is involved in cell migration and proliferation in lung cancer. ${ }^{36}$ These results point toward an intriguing role of the keratins in lung fibrosis, inflammation, and cancer.

Furthermore, in the analyzed OB lesions, a multitude of proteins (maximum, 89/lesion-minimum, 30/lesion) were identified, thereby dismissing the hypothesis that the airway lesions are composed of only a few characteristic proteins, which highlights the complexity of the disease and underlines the need to identify the earliest disease events and cells responsible for producing fibrogenic proteins. 

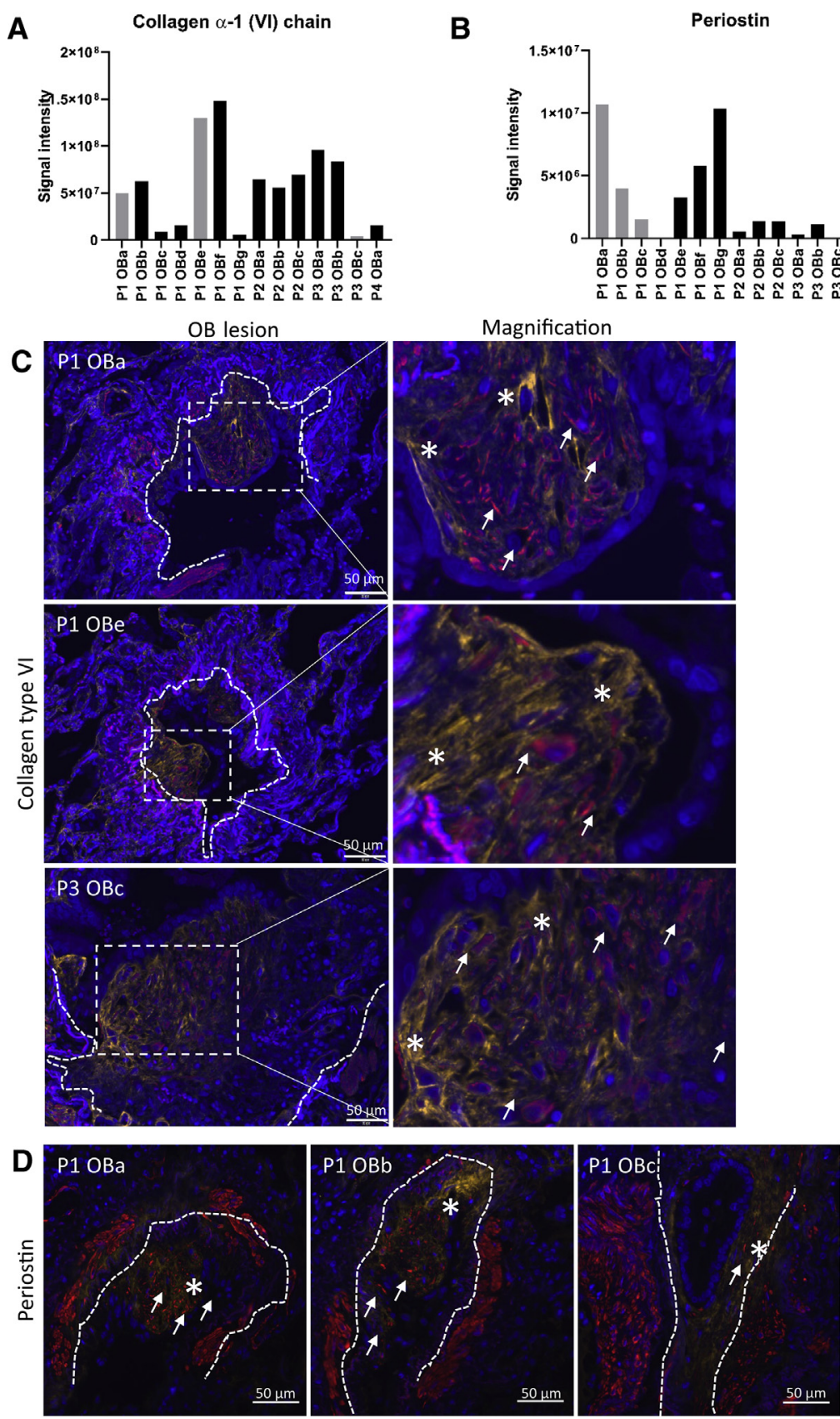

Figure 7 Collagen type VI/ $\alpha$-smooth muscle actin ( $\alpha$ SMA) immunofluorescence (IF). Corresponding signal intensities from laser-dissected regions analyzed by mass spectrometry for the collagen type VI (A) or periostin (B). IF staining for collagen type VI (yellow; $\mathbf{C}$ ) and periostin (yellow; $\mathbf{D}$ ) together with $\alpha$-SMA (red; $\mathbf{C}$ and $\mathbf{D}$ ) in selected obliterative bronchiolitis ( $\mathrm{OB}$ ) lesions. Asterisks indicate strong collagen type VI or periostin deposition; arrows, single $\alpha$-SMA-positive cells; blue, nuclei; white dashed lines, area within the smooth muscle ring. Scale bars $=$ $50 \mu \mathrm{m}$ (C and D). P1 to P4, Patients 1 to 4 .
Furthermore, both MS data and histologic visualization of proteins, like collagen type VI and periostin, showed pathologic deposition. The BM protein collagen type IV showed an unusual distribution by being accumulated outside the usual epithelial BM, most likely evidence of a disturbed epithelial/mesenchymal balance in the OB lesion. Collagen types IV and VI are two of several proteins in the BM, and the loss of their integrity causes an abnormal lung architecture thought to promote fibrosis. Interestingly, these proteins are known to have both adhesive and antimicrobial properties, and act as key players in connective tissue innate immunity. ${ }^{37-39}$ In addition, periostin has been shown to promote myofibroblast differentiation and collagen type I production, and studies to date suggest that periostin could be a useful biomarker for clinical progression in lung disease, resulting in various types of fibrosis. ${ }^{40}$

Both hematologically derived mononuclear phagocytes and epithelial-mesenchymal transition have been proposed as sources of myofibroblasts that are responsible for the fibrogenesis in the OB lesions. ${ }^{41-43}$ Indeed, the examined lesions in this study contained a multitude of $\alpha$-SMA-/ vimentin-positive, elongated cells, with morphologic and immunohistochemical features of myofibroblasts. Interestingly, transgelin, a TGF- $\beta$ inducible protein detected in the 
OB lesions (Figure 5), is an early marker of myofibroblast differentiation, and has previously been shown to be involved in epithelial cell migration in idiopathic pulmonary fibrosis. $^{44}$

Fibrocytes may be recruited from the circulation into the OB lesion as producers of proteins commonly found in fibrotic tissue. ${ }^{45}$ Moreover, macrophages of donor origin have been indicated to mediate fibrosis in OB lesions following bone marrow transplantation through the action of TGF- $\beta .{ }^{46}$ More important, macrophages are often localized in close proximity to collagen-producing myofibroblasts and have been suggested to be master regulators of fibrosis. ${ }^{47}$ Indeed, TGF- $\beta$ promotes synthesis of collagen and other extracellular matrix molecules, such as hyaluronan and proteoglycans. ${ }^{46,48}$ TGF- $\beta$ also induces tissue inhibitors of matrix metalloproteases that are involved in fibrosis by blocking extracellular matrix degradation. In fact, in bronchiolitis obliterans, the balance of tissue inhibitors of matrix metalloproteases and matrix metalloproteases is altered, and especially the matrix metalloprotease- 8 , matrix metalloprotease-9, and tissue inhibitor of matrix metalloprotease- 1 that we found are mirrored in bronchoalveolar lavage fluid from patients and may serve as biomarkers for prognosis. ${ }^{49}$ This may reflect a polarization toward profibrotic macrophages, which are characterized by their expression of tissue inhibitor of matrix metalloprotease-1, matrix metalloprotease- 9 , and TGF- $\beta$, among other molecules. ${ }^{50}$ Another cell type that has been proposed to be involved in the fibrotic propagation in $\mathrm{OB}$ lesions is the mast cell. ${ }^{51}$ Interestingly, the mast cell protein tryptase was identified in all examined lesions. Mast cell abundance correlates to myofibroblasts expressing $\alpha$-SMA in human pulmonary fibrosis, ${ }^{52,53}$ and the stiff extracellular matrix in OB lesions itself has an inductive effect on mast cells and their release of tryptase and chymase, which activate profibrotic TGF- $\beta$ pathways. ${ }^{54}$

The protein signatures of the $\mathrm{OB}$ lesions reported herein mirror the heterogeneity seen at the histologic level. This study found that the OB lesions differed within and among patients. Interestingly, two suspected lesions were identified in Patient 2, which differed by exhibiting smooth muscle hypertrophy and a deviating protein pattern (Figure 4). More efforts are needed to further subgroup these different subtypes and to understand the functional implications of the accumulated proteins. Functional annotations underline the importance of the identified proteins in the context of extracellular matrix remodeling and highlight pathways belonging to tissue development and wound healing, processes that are suspected to play a role in the development of chronic lung allograft dysfunction. ${ }^{29,55,56}$

Although the low patient number and the inability to follow the progression of lesions over time are distinct drawbacks, this study gives a snapshot of ongoing disease activity, including cellular pathways involving extracellular structure organization, tissue development, and response to wounding. These results persist after analyzing the data, excluding the single sample obtained from Patient 4, supporting the validity of the data. In line with this, the study presents an unbiased and idea-generating approach to identify key cellular events in the course of BOS and provides a unique window into the nature of remodeled pathologic airways after lung transplantation. Other studies have focused on predicting BOS in lung transplanted patients by analyzing the bronchoalveolar lavage proteome, which has yielded several potential predictive markers as well as suggestive cellular pathways indicative of future BOS development. ${ }^{57,58}$ In conclusion, this study adds to the understanding of the formation of OB lesions, and the identification of early processes, and preferably their triggering events, will facilitate future development of tools to counteract fibrosis before symptomatic manifestation.

\section{Acknowledgments}

We thank Ingrid Hedenfalk (Lund University) and Anna Ebbesson (Lund University) for providing the laser-capture microscopy infrastructure and support.

\section{Supplemental Data}

Supplemental material for this article can be found at http://doi.org/10.1016/j.ajpath.2021.05.014.

\section{References}

1. Cooper JD, Billingham M, Egan T, Hertz MI, Higenbottam T, Lynch J, Mauer J, Paradis I, Patterson GA, Smith C, Trulock EP, Vreim C, Yousem S; International Society for Heart and Lung Transplantation: A working formulation for the standardization of nomenclature and for clinical staging of chronic dysfunction in lung allografts. J Heart Lung Transplant 1993, 12:713-716

2. Estenne M, Maurer JR, Boehler A, Egan JJ, Frost A, Hertz M, Mallory GB, Snell GI, Yousem S: Bronchiolitis obliterans syndrome 2001: an update of the diagnostic criteria. J Heart Lung Transplant 2002, 21:297-310

3. Meyer KC, Raghu G, Verleden GM, Corris PA, Aurora P, Wilson KC, Brozek J, Glanville AR: An international ISHLT/ATS/ERS clinical practice guideline: diagnosis and management of bronchiolitis obliterans syndrome. Eur Respir J 2014, 44:1479-1503

4. Verleden GM, Glanville AR, Lease ED, Fisher AJ, Calabrese F, Corris PA, Ensor CR, Gottlieb J, Hachem RR, Lama V, Martinu T, Neil DAH, Singer LG, Snell G, Vos R: Chronic lung allograft dysfunction: definition, diagnostic criteria, and approaches to treatment-a consensus report from the Pulmonary Council of the ISHLT. J Heart Lung Transpl 2019, 38:493-503

5. Burton CM, Carlsen J, Mortensen J, Andersen CB, Milman N, Iversen M: Long-term survival after lung transplantation depends on development and severity of bronchiolitis obliterans syndrome. J Heart Lung Transplant 2007, 26:681-686

6. Kulkarni HS, Cherikh WS, Chambers DC, Garcia VC, Hachem RR, Kreisel D, Puri V, Kozower BD, Byers DE, Witt CA, AlexanderBrett J, Aguilar PR, Tague LK, Furuya Y, Patterson GA, Trulock EP 3rd, Yusen RD: Bronchiolitis obliterans syndrome-free survival after lung transplantation: an International Society for Heart and Lung Transplantation Thoracic Transplant Registry analysis. J Heart Lung Transplant 2019, 38:5-16 
7. Verleden GM, Raghu G, Meyer KC, Glanville AR, Corris P: A new classification system for chronic lung allograft dysfunction. J Heart Lung Transplant 2014, 33:127-133

8. Sato M, Waddell TK, Wagnetz U, Roberts HC, Hwang DM, Haroon A, Wagnetz D, Chaparro C, Singer LG, Hutcheon MA, Keshavjee S: Restrictive allograft syndrome (RAS): a novel form of chronic lung allograft dysfunction. J Heart Lung Transplant 2011, 30:735-742

9. Estenne M, Hertz MI: Bronchiolitis obliterans after human lung transplantation. Am J Respir Crit Care Med 2002, 166:440-444

10. Todd JL, Palmer SM: Bronchiolitis obliterans syndrome: the final frontier for lung transplantation. Chest 2011, 140:502-508

11. Vandermeulen E, Lammertyn E, Verleden SE, Ruttens D, Bellon H, Ricciardi M, Somers J, Bracke KR, Van Den Eynde K, Tousseyn T, Brusselle GG, Verbeken EK, Verschakelen J, Emonds MP, Van Raemdonck DE, Verleden GM, Vos R, Vanaudenaerde BM: Immunological diversity in phenotypes of chronic lung allograft dysfunction: a comprehensive immunohistochemical analysis. Transpl Int 2017, 30:134-143

12. von der Thusen JH, Vandermeulen E, Vos R, Weynand B, Verbeken EK, Verleden SE: The histomorphological spectrum of restrictive chronic lung allograft dysfunction and implications for prognosis. Mod Pathol 2018, 31:780-790

13. Verleden SE, Vasilescu DM, McDonough JE, Ruttens D, Vos R, Vandermeulen E, Bellon H, Geenens R, Verbeken EK, Verschakelen J, Van Raemdonck DE, Wuyts WA, Sokolow Y, Knoop C, Cooper JD, Hogg JC, Verleden GM, Vanaudenaerde BM: Linking clinical phenotypes of chronic lung allograft dysfunction to changes in lung structure. Eur Respir J 2015, 46:1430-1439

14. Levy L, Tigert A, Huszti E, Saito T, Mitsakakis N, Moshkelgosha S, Joe B, Boonstra KM, Tikkanen JM, Keshavjee S, Juvet SC, Martinu T: Epithelial cell death markers in bronchoalveolar lavage correlate with chronic lung allograft dysfunction subtypes and survival in lung transplant recipients-a single-center retrospective cohort study. Transpl Int 2019, 32:965-973

15. Andersson-Sjoland A, Thiman L, Nihlberg K, Hallgren O, Rolandsson S, Skog I, Mared L, Hansson L, Eriksson L, Bjermer L, Westergren-Thorsson G: Fibroblast phenotypes and their activity are changed in the wound healing process after lung transplantation. J Heart Lung Transplant 2011, 30:945-954

16. Verleden SE, Vasilescu DM, Willems S, Ruttens D, Vos R, Vandermeulen E, Hostens J, McDonough JE, Verbeken EK, Verschakelen J, Van Raemdonck DE, Rondelet B, Knoop C, Decramer M, Cooper J, Hogg JC, Verleden GM, Vanaudenaerde BM: The site and nature of airway obstruction after lung transplantation. Am J Respir Crit Care Med 2014, 189:292-300

17. Weigt SS, Shino MY, Wang X: Molecular diagnostics for lung transplant rejection: an information pipeline or a pipe dream? J Heart Lung Transplant 2019, 38:514-515

18. Verleden SE, McDonough JE, Schoemans H, Knoop C, Verschakelen J, Dubbeldam A, Boone MN, Van Hoorebeke L, Verbeken E, Weynand B, Van Raemdonck D, Verleden GM, Vos R, Vanaudenaerde BM: Phenotypical diversity of airway morphology in chronic lung graft vs. host disease after stem cell transplantation. Mod Pathol 2019, 32:817-829

19. Jonigk D, Izykowski N, Rische J, Braubach P, Kuhnel M, Warnecke G, Lippmann T, Kreipe H, Haverich A, Welte T, Gottlieb J, Laenger F: Molecular profiling in lung biopsies of human pulmonary allografts to predict chronic lung allograft dysfunction. Am J Pathol 2015, 185:3178-3188

20. Kuehnel M, Maegel L, Vogel-Claussen J, Robertus JL, Jonigk D: Airway remodelling in the transplanted lung. Cell Tissue Res 2017, 367:663-675

21. Morgan DL, Merrick BA, Gerrish KE, Stockton PS, Wang Y, Foley JF, Gwinn WM, Kelly FL, Palmer SM, Ton TV, Flake GP: Gene expression in obliterative bronchiolitis-like lesions in 2,3pentanedione-exposed rats. PLoS One 2015, 10:e118459

22. Rosmark O, Ahrman E, Muller C, Elowsson Rendin L, Eriksson L, Malmstrom A, Hallgren O, Larsson-Callerfelt AK, Westergren-
Thorsson G, Malmstrom J: Quantifying extracellular matrix turnover in human lung scaffold cultures. Sci Rep 2018, 8:5409

23. Todd JL, Wang X, Sugimoto S, Kennedy VE, Zhang HL, Pavlisko EN, Kelly FL, Huang H, Kreisel D, Palmer SM, Gelman AE: Hyaluronan contributes to bronchiolitis obliterans syndrome and stimulates lung allograft rejection through activation of innate immunity. Am J Respir Crit Care Med 2014, 189:556-566

24. Braakman RB, Stingl C, Tilanus-Linthorst MM, van Deurzen CH, Timmermans MA, Smid M, Foekens JA, Luider TM, Martens JW, Umar A: Proteomic characterization of microdissected breast tissue environment provides a protein-level overview of malignant transformation. Proteomics 2017, 17:1600213

25. Hughes CS, Foehr S, Garfield DA, Furlong EE, Steinmetz LM, Krijgsveld J: Ultrasensitive proteome analysis using paramagnetic bead technology. Mol Syst Biol 2014, 10:757

26. Vizcaino JA, Cote RG, Csordas A, Dianes JA, Fabregat A, Foster JM, Griss J, Alpi E, Birim M, Contell J, O’Kelly G, Schoenegger A, Ovelleiro D, Perez-Riverol Y, Reisinger F, Rios D, Wang R, Hermjakob H: The PRoteomics IDEntifications (PRIDE) database and associated tools: status in 2013. Nucleic Acids Res 2013, 41: D1063-D1069

27. Naba A, Clauser KR, Hoersch S, Liu H, Carr SA, Hynes RO: The matrisome: in silico definition and in vivo characterization by proteomics of normal and tumor extracellular matrices. Mol Cell Proteomics 2012, 11. M111.014647

28. Naba A, Hoersch S, Hynes RO: Towards definition of an ECM parts list: an advance on GO categories. Matrix Biol 2012, 31:371-372

29. Muller C, Andersson-Sjoland A, Schultz HH, Eriksson LT, Andersen CB, Iversen M, Westergren-Thorsson G: Early extracellular matrix changes are associated with later development of bronchiolitis obliterans syndrome after lung transplantation. BMJ Open Respir Res 2017, 4:e00177

30. Larsson-Callerfelt AK, Muller C, Andersson-Sjoland A, Thiman L, Larsson H, Hallgren O, Bjermer L, Eriksson L, WestergrenThorsson G: VEGF synthesis and VEGF receptor 2 expression in patients with bronchiolitis obliterans syndrome after lung transplantation. Respir Med 2020, 166:105944

31. Boivin WA, Shackleford M, Vanden Hoek A, Zhao H, Hackett TL, Knight DA, Granville DJ: Granzyme B cleaves decorin, biglycan and soluble betaglycan, releasing active transforming growth factor-beta1. PLoS One 2012, 7:e33163

32. Tufvesson E, Westergren-Thorsson G: Biglycan and decorin induce morphological and cytoskeletal changes involving signalling by the small GTPases RhoA and Rac1 resulting in lung fibroblast migration. J Cell Sci 2003, 116:4857-4864

33. Karantza V: Keratins in health and cancer: more than mere epithelial cell markers. Oncogene 2011, 30:127-138

34. Ficial M, Antonaglia C, Chilosi M, Santagiuliana M, Tahseen AO, Confalonieri D, Zandona L, Bussani R, Confalonieri M: Keratin-14 expression in pneumocytes as a marker of lung regeneration/repair during diffuse alveolar damage. Am J Respir Crit Care Med 2014, 189:1142-1145

35. Confalonieri M, Buratti E, Grassi G, Bussani R, Chilosi M, Farra R, Abrami M, Stuani C, Salton F, Ficial M, Confalonieri P, Zandona L, Romano M: Keratin14 mRNA expression in human pneumocytes during quiescence, repair and disease. PLoS One 2017, 12:e0172130

36. Hu HB, Yang XP, Zhou PX, Yang XA, Yin B: High expression of keratin $6 \mathrm{C}$ is associated with poor prognosis and accelerates cancer proliferation and migration by modulating epithelial-mesenchymal transition in lung adenocarcinoma. Genes Genomics 2020, 42:179-188

37. Strieter RM: What differentiates normal lung repair and fibrosis? inflammation, resolution of repair, and fibrosis. Proc Am Thorac Soc 2008, 5:305-310

38. Abdillahi SM, Tati R, Nordin SL, Baumgarten M, Hallgren O, Bjermer L, Erjefalt J, Westergren-Thorsson G, Singh B, Riesbeck K, Morgelin M: The pulmonary extracellular matrix is a bactericidal barrier against haemophilus influenzae in chronic obstructive 
pulmonary disease (COPD): implications for an in vivo innate host defense function of collagen VI. Front Immunol 2018, 9:1988

39. Elowsson Rendin L, Lofdahl A, Ahrman E, Muller C, Notermans T, Michalikova B, Rosmark O, Zhou XH, Dellgren G, Silverborn M, Bjermer L, Malmstrom A, Larsson-Callerfelt AK, Isaksson $\mathrm{H}$, Malmstrom J, Westergren-Thorsson G: Matrisome properties of scaffolds direct fibroblasts in idiopathic pulmonary fibrosis. Int J Mol Sci 2019, 20:4013

40. O'Dwyer DN, Moore BB: The role of periostin in lung fibrosis and airway remodeling. Cell Mol Life Sci 2017, 74:4305-4314

41. Di Campli MP, Azouz A, Assabban A, Scaillet J, Splittgerber M, Van Keymeulen A, Libert F, Remmelink M, Le Moine A, Lemaitre P, Goriely S: The mononuclear phagocyte system contributes to fibrosis in post-transplant obliterans bronchiolitis. Eur Respir J 2021, 57:2000344

42. Brocker V, Lehmann U, Langer F, Fellous TG, Mengel M, Brittan M, Bredt M, Milde S, Welte T, Eder M, Haverich A, Alison MR, Kreipe H: [Fibroblasts of recipient origin contribute to broncholitis obliterans in human lung transplants] German. Verh Dtsch Ges Pathol 2006, 90:277-285

43. Bansal R, Nakagawa S, Yazdani S, van Baarlen J, Venkatesh A, Koh AP, Song WM, Goossens N, Watanabe H, Beasley MB, Powell CA, Storm G, Kaminski N, van Goor H, Friedman SL, Hoshida Y, Prakash J: Integrin alpha 11 in the regulation of the myofibroblast phenotype: implications for fibrotic diseases. Exp Mol Med 2017, 49:e396

44. Yu H, Konigshoff M, Jayachandran A, Handley D, Seeger W, Kaminski N, Eickelberg O: Transgelin is a direct target of TGFbeta/Smad3-dependent epithelial cell migration in lung fibrosis. FASEB J 2008, 22:1778-1789

45. Andersson-Sjoland A, Erjefalt JS, Bjermer L, Eriksson L, Westergren-Thorsson G: Fibrocytes are associated with vascular and parenchymal remodelling in patients with obliterative bronchiolitis. Respir Res 2009, 10:103

46. Alexander KA, Flynn R, Lineburg KE, Kuns RD, Teal BE, Olver SD, Lor M, Raffelt NC, Koyama M, Leveque L, Le Texier L, Melino M, Markey KA, Varelias A, Engwerda C, Serody JS, Janela B, Ginhoux F, Clouston AD, Blazar BR, Hill GR, MacDonald KP: CSF1-dependant donor-derived macrophages mediate chronic graftversus-host disease. J Clin Invest 2014, 124:4266-4280

47. Wynn TA, Barron L: Macrophages: master regulators of inflammation and fibrosis. Semin Liver Dis 2010, 30:245-257

48. Westergren-Thorsson G, Sarnstrand B, Fransson LA, Malmstrom A: TGF-beta enhances the production of hyaluronan in human lung but not in skin fibroblasts. Exp Cell Res 1990, 186: 192-195

49. Taghavi S, Krenn K, Jaksch P, Klepetko W, Aharinejad S: Bronchoalveolar lavage matrix metalloproteases as a sensitive measure of bronchiolitis obliterans. Am J Transplant 2005, 5:1548-1552

50. Barisione C, Garibaldi S, Furfaro AL, Nitti M, Palmieri D, Passalacqua M, Garuti A, Verzola D, Parodi A, Ameri P, Altieri P, Fabbi P, Ferrar PF, Brunelli C, Arsenescu V, Balbi M, Palombo D, Ghigliotti G: Moderate increase of indoxyl sulfate promotes monocyte transition into profibrotic macrophages. PLoS One 2016, 11: e0149276

51. Mortaz E, Amani S, Mumby S, Adcock IM, Movassaghi M, Folkerts J, Garssen J, Folkerts G: Role of mast cells and type 2 innate lymphoid (ILC2) cells in lung transplantation. J Immunol Res 2018, 2018:2785971

52. Hirata K, Sugama Y, Ikura Y, Ohsawa M, Inoue Y, Yamamoto S, Kitaichi M, Ueda M: Enhanced mast cell chymase expression in human idiopathic interstitial pneumonia. Int J Mol Med 2007, 19: $565-570$

53. Andersson CK, Andersson-Sjoland A, Mori M, Hallgren O, Pardo A, Eriksson L, Bjermer L, Lofdahl CG, Selman M, WestergrenThorsson G, Erjefalt JS: Activated MCTC mast cells infiltrate diseased lung areas in cystic fibrosis and idiopathic pulmonary fibrosis. Respir Res 2011, 12:139

54. Shimbori C, Upagupta C, Bellaye PS, Ayaub EA, Sato S, Yanagihara T, Zhou Q, Ognjanovic A, Ask K, Gauldie J, Forsythe P, Kolb MRJ: Mechanical stress-induced mast cell degranulation activates TGF-beta1 signalling pathway in pulmonary fibrosis. Thorax 2019, 74:455-465

55. Borthwick LA, Parker SM, Brougham KA, Johnson GE, Gorowiec MR, Ward C, Lordan JL, Corris PA, Kirby JA, Fisher AJ: Epithelial to mesenchymal transition (EMT) and airway remodelling after human lung transplantation. Thorax 2009, 64:770-777

56. Babu AN, Nicolls MR: The matrix comes to lung transplantation. Transplantation 2007, 83:683-684

57. Wolf T, Oumeraci T, Gottlieb J, Pich A, Brors B, Eils R, Haverich A, Schlegelberger B, Welte T, Zapatka M, von Neuhoff N: Proteomic bronchiolitis obliterans syndrome risk monitoring in lung transplant recipients. Transplantation 2011, 92:477-485

58. Meloni F, Salvini R, Bardoni AM, Passadore I, Solari N, Vitulo P, Oggionni T, Vigano M, Pozzi E, Fietta AM: Bronchoalveolar lavage fluid proteome in bronchiolitis obliterans syndrome: possible role for surfactant protein A in disease onset. J Heart Lung Transplant 2007, 26:1135-1143 